\title{
Response of Orthoptera to clear-cuts in beech forests
}

\author{
AnNa SLIACKA, ANTON KRIŠTíN and LadisLAv NAĎO \\ Institute of Forest Ecology, Department of Animal Ecology, L. Štúra 2, SK-96053 Zvolen, Slovakia; \\ e-mails: asliacka@savzv.sk; kristin@savzv.sk
}

Key words. Ecology, Orthoptera, beech forest, forest succession, vegetation structure, central Europe

\begin{abstract}
Various disturbances in forests often result in the formation of open habitats with characteristics that are distinctly different from those of the original forest (microclimate, illumination, stand age and composition). These disturbances affect the habitat heterogeneity in time and space and seem to drive forest succession and changes in biodiversity in forests. Little is known about how the colonization of deforested habitats by Orthoptera is influenced by environmental factors. We studied the association between the structure of orthopteran assemblages and the age of clear-cuts, vegetation structure and other environmental parameters (size, elevation, altitude). This involved 33 clear-cuts of three age categories in broadleaved forests dominated by European beech. The Orthoptera were sampled using sweep netting and by counting individuals recorded along transects that ran parallel to those used for recording the structure of the vegetation. We recorded significant differences in the number and abundance of species in the three age categories of clear-cuts. Grasshopper species were more abundant than bush-crickets in first year clear-cuts. Species capable of flight occured in all three age categories of clear-cuts ( $>62 \%$ of the 27 species recorded). All the species of Orthoptera identified were present in two year-old clear-cuts. The species composition and abundance of Ensifera and Caelifera differed in their association with the six vegetation parameters studied. While the Caelifera occurred in habitats with bare ground the Ensifera mainly occurred in those with a higher proportion of shrubs and trees. There was also a positive correlation between number of species of Orthoptera and area of the clear-cut regardless of its age as well between the number of species of Orthoptera and elevation.
\end{abstract}

\section{INTRODUCTION}

The forest environment is subject to natural disturbances (wind, deep snow, fire and floods) as well as human exploitation (Schelhaas et al., 2003). For heliophilous insects large areas of closed canopy forests act as barriers to dispersal and can cause their genetic isolation (Kohlmann \& Schaw, 1991). Linear landscape elements, nodes and landscape connectivity facilitate the colonization process, settlement and survival of species in newly established habitats (Berggren et al., 2001, 2002; Jordán et al., 2003). Hence, the fragmentation of forests and the creation of open habitats and a great variety of microhabitats favours heliophilous arthropods (e.g. Willott et al., 2000; Konvička et al., 2004; Niemelä et al., 2007; Vele et al., 2011). Colonization of newly opened up plots in closed-canopy woodlands by heliophilous insects, such as Orthoptera and Lepidoptera, starts immediately after the establishment of such plots (Laußmann, 1993; Willott et al., 2000). Based on this knowledge, rapid colonization of newly established deforested plots (e.g. clear-cuts) by Orthoptera living in surrounding sparse forest and forest edges is to be expected. Forest edges are also an important source habitat, e.g., for the recolonization by Orthoptera of managed (mown) meadows (Guido \& Gianelle, 2001; Marini et al., 2009b). In the case of insects capable of flight, even more distant habitats can act as sources of colonizers (Buchweitz, 1993; Detzel, 1998). These pioneer species are good dispersers and are able to colonize quickly newly created habitats (Picaud \& Petid, 2007; Hochkirch et al., 2008). However, even the colonization by short-winged or less mobile species can be quite rapid
(Jenni et al., 2007). Furthermore, the dispersal ability of some species of Orthoptera can be influenced by wing polymorphism, caused by changing environmental conditions (Harrison, 1980; Poniatowski \& Fartmann, 2011a, b). High numbers and abundance of species is associated with a high diversity of plants and of types of vegetation in different habitats (Bergmann \& Chaplin, 1992; Guido \& Gianelle, 2001; Picaud \& Petit, 2007; Branson, 2011). For example, the diversity of Orthoptera in open habitats can be higher if there are shrubs and trees present (Kati et al., 2003; Marini et al., 2009b). The colonization of open plots by heliophilous species is not permanent, however, because these species decline in abundance in these plots as succession proceeds (e.g. Marini et al., 2009b; Vele et al., 2011; Fartmann et al., 2012). On the other hand, felling trees in large closed canopy forests can temporarily increase the biodiversity and in particular for the study reported here, the diversity of heliophilous insects (Kati et al., 2003; Konvička et al., 2004). However, little is known about how Orthoptera living on clear-cuts respond to changes in the structure of the vegetation.

The area of open habitats, corridors and roads in forests are important factors affecting the occurrence of Orthoptera in forests (Theuerkauf \& Rouys, 2006). A positive correlation between the diversity of Orthoptera and clear-cut area is reported by Bergmann \& Chaplin (1992). However, there is a lack of knowledge on how the colonization of clear-cuts by Orthoptera in the first years after deforestation is affected by environmental factors.

Several papers address the effects of deforestation (cutting, fire) on the occurrence of Orthoptera in coniferous 


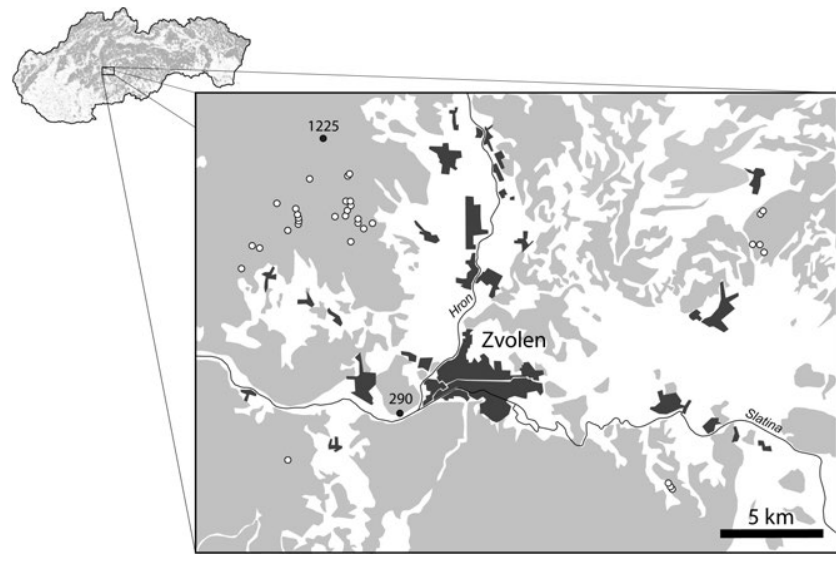

Fig. 1. Location of the 33 clear-cuts (white circles) studied in Central Slovakia, (forest areas - grey, non-forest habitats white, settlements - black, extreme altitudes in the area - black dots).

forests (Bergmann \& Chaplin, 1992; Clayton, 2002; Jenni et al., 2007). On the other hand, there are fewer studies on the Orthoptera that inhabit clear-cuts in broadleaved forests. Laußmann (1993) report the structure of Orthoptera assemblages in only two plots in a mixed beech forest (North Bavaria) and for the first two years following deforestation. Therefore, in this study, we focussed on the response of assemblages of Orthoptera (as bioindicators of open habitats) to deforestation and formation of clearcuts in broadleaved forests dominated by beech. Our specific aims were:

(i) to investigate the effect of succession and other environmental factors on the abundance and number of species in assemblages of Orthoptera and (ii) identify the effect of habitat vegetation structure and clear-cut age on the occurrence of species of Ensifera and Caelifera, separately.

\section{MATERIAL AND METHODS}

The study plots in clear-cuts $(n=33)$ were in extensively managed, fragmented forests on south, SE and SW facing slopes in the Western Carpathians Mts (460-740 m a.s.l., Kremnické vrchy Mts, Štiavnické vrchy Mts, Pol'ana and Javorie Mts, Fig. 1). The surrounding forest mainly consisted of beech $(70-90 \%)$ with oak, hornbeam, fir, spruce and lime (0-30\%). Based on the time since the areas were clear felled, we divided the clear-cuts into three age categories: first-year ("age1", $\mathrm{n}=11$ ); second- year ("age2", $\mathrm{n}=11$ ) and several-years ("age 3", 3-7 years since felled, $n=11$ ). In addition, the clear-cuts were managed in three different ways: (a) a number of solitary adult trees of the original stand were not felled and used as a source of seed, which ensured natural regeneration; (b) replanted with seedlings of mainly beech and spruce (yes $1 /$ no 0 ); (c) or they were mown (yes $1 /$ no 0 ) (Table 1 ).

\section{Data collection}

Data on orthopteran assemblages were collected in June and August of 2011 (always during the second half of the month) and when weather conditions were favourable (sunny or halfcloud and not raining, between 10 a.m. and 5 p.m.). We used two independent methods: (a) by counting the numbers of each species and of individuals along transects, identified visually or acoustically, and (b) by sweep netting (Gardiner et al., 2005):

(a) In each clear-cut, we delineated four transects $(30 \times 1 \mathrm{~m})$ at regular intervals of $10 \mathrm{~m}$. The minimum distance from the forest edge was $5 \mathrm{~m}$. The structure of the orthopteran assemblages (number and abundance of the species/taxons) was recorded while slowly walking along each transect (10 min/transect) taking care not to disturb the insects.

(b) Number and abundance of species/taxons were also obtained by sweeping ( 250 sweeps/clear-cut). One sweep means moving once back and forth in one direction (Gardiner et al., 2005). We recorded the number caught using a round shaped (Ø $=35 \mathrm{~cm}$ ) sweep net and those recorded visually and acoustically. Sweep netting was carried out along a line that included as many microhabitats as possible (bare ground, low and high growing herbaceous plants and grasses, Rubus spp., seedlings and saplings of forest woody plants) but did not cross the transects.

Altogether we recorded 6538 individuals, 5113 (78.2\%) of them were identified to species level. The unidentified individuals (1425) were not-caught adults and nymphs of the genus Tetrix, and nymphs of the genera Tettigonia, Phaneroptera and family Acrididae. Such individuals were rarely sampled because it was difficult identify them as there are cryptic species in the genera Tetrix and Chorthippus. All other Orthoptera were identified and classified using the keys of Kočárek et al., (2005).

Vegetation structure was recorded along the same transects as the insects and each transect was divided into $6 \mathrm{~m}$ segments. We recorded the cover (\%) of four easily recognised categories of vegetation (grass, herbaceous plants, shrubs, Rubus spp.) and of bare ground (cf. Poore, 1955). The height of the vegetation was calculated as the mean height of all categories of vegetation along all transects sampled, which was measured immediately after sampling the insects.

The altitude, elevation and area of the clear-cuts (min size $>$ $2000 \mathrm{~m}^{2}$ ) were recorded using GPS navigation (Table 1). The

TABLE 1. Means ( \pm SD) of the continuous characteristics of the 33 clear-cuts in beech forests studied; numbers in the management category is the mean number of clear-cuts managed in particular ways.

\begin{tabular}{|c|c|c|c|}
\hline Parameter & "age1" & "age2" & "age3" \\
\hline Age & 1 year & 2 years & $3-7$ years \\
\hline Number of sites & 11 & 11 & 11 \\
\hline Area $\left(m^{2}\right)$ & $4552 \pm 1845$ & $7445 \pm 3959$ & $9770 \pm 4529$ \\
\hline Altitude (m a. s. 1.) & $587 \pm 70$ & $560.5 \pm 89.9$ & $625.5 \pm 101.9$ \\
\hline Elevation (m) & $32 \pm 15.7$ & $60 \pm 28.7$ & $41 \pm 17.4$ \\
\hline Aspect & $\mathrm{E}, \mathrm{S}, \mathrm{SW}, \mathrm{W}$ & E, SE, SW, W,NW & S, SW, W \\
\hline Management of clear-cuts & 7 & 7 & 10 \\
\hline (a) solitary trees & 5 & 1 & 5 \\
\hline (b) planted & 2 & 2 & 2 \\
\hline (c) mown & 0 & 4 & 7 \\
\hline
\end{tabular}



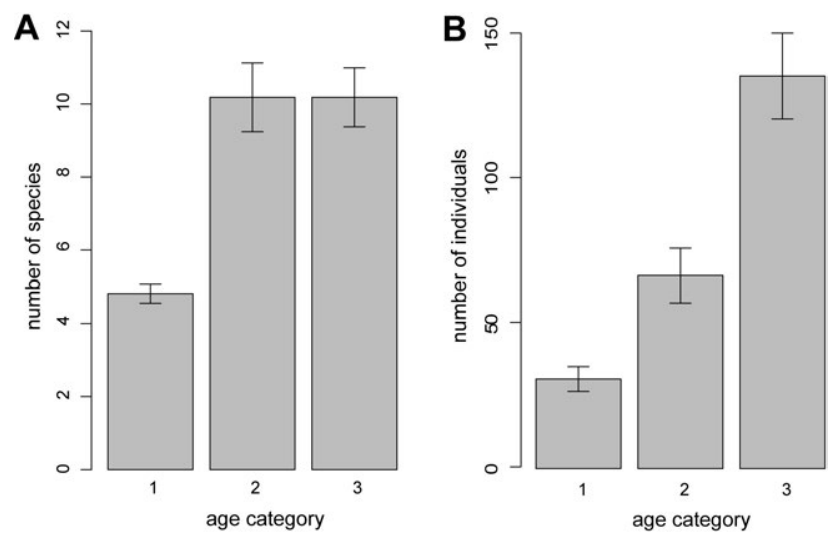

Fig. 2. Number of species (A) and abundance of Orthoptera (B) recorded in clear-cuts of three different age categories $(1=$ "age1", 2 = "age2", 3 = "age3").

area of the clear-cuts was measured during sampling of the plots using a projection polygon of the crowns of the trees on the edges of each clear-cut.

\section{Data analysis}

The number of species and individuals in the clear-cuts of different ages (Fig. 2) were compared using one-way ANOVA followed by Tukey multiple comparisons of means $(p<0.001)$. The 33 clear-cuts were classified based on the number of species of Orthoptera using Discriminant Function Analysis (DFA, Fig. 3). The species Chorthippus dorsatus and Chorthippus montanus that occurred at very low frequencies (recorded in only two clear-cuts) were excluded from the analyses. The association of the number of species of Orthoptera with abiotic characteristics of clear-cuts (area, elevation) was tested using either the parametric Pearson's or non-parametric Spearman's correlation tests.

The association between the number of species of Ensifera and Caelifera and the age and structure of the vegetation was analysed using Canonical Correspondence Analysis (CCA in the following text) using the vegan package (Oksanen et al., 2012). Three clear-cut age categories (age1, age2, age3) and six vegetation categories (bare ground, grass, herbaceous plants, shrubs, Rubus spp., height of vegetation) were considered. All the statistical analyses and evaluations were performed in Statistica 7 (Statsoft Inc., 2004) and "R 2.13.2" (R Development Core Team, 2011).

\section{RESULTS}

\section{Orthopteran assemblages, age and abiotic characteristics of clear-cuts}

Altogether 27 species (12 Ensifera, 15 Caelifera) were recorded in 33 clear-cuts of three age categories. Most species were found in two-year-old clear-cuts (26 species), followed by several-year-old clear-cuts ( 25 species) and ending with (16 species) in one-year-old clearcuts (Table 2). The most frequent of these was Pholidoptera griseoaptera, which occurred in all clearcuts. Of the 27 species recorded, $66.7 \%$ were capable of flight: 10 of which were found in "age1", 18 in "age2" and 17 in "age3" clear-cuts. Very frequent, regardless of clear-cut age, were the long-winged species Chorthippus brunneus (75.8\% of all plots), Chorthippus vagans (93.9\%) and Tetrix undulata (69.7\%). High frequencies of no other species were recorded in first-year clear-cuts.

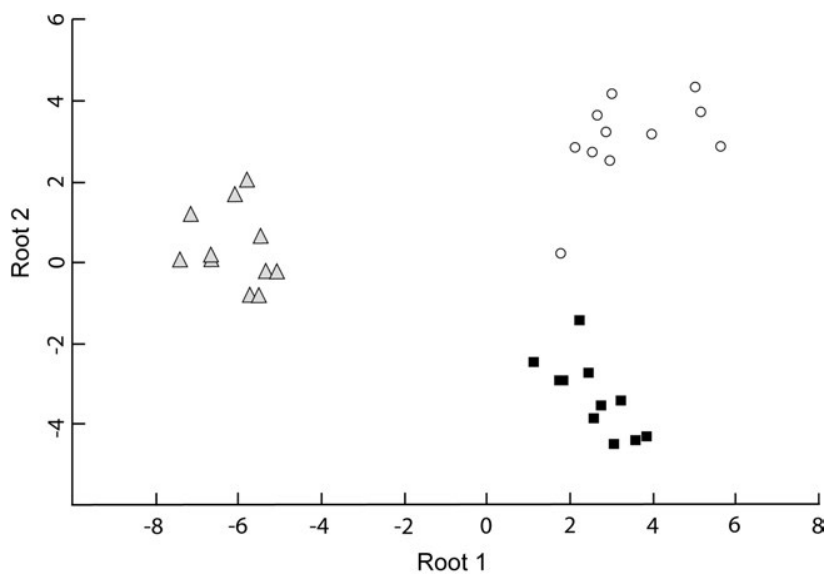

Fig. 3. Classification of three age categories of clear-cuts (clear-cut "age1", clear-cut "age2", clear-cut "age3") based on the DFA of the number of species and abundance of Orthoptera. The Orthoptera included in the model are shown in Table 3.

The two- and several-year-old clear-cuts frequently hosted the bush-crickets Tettigonia cantans, Phaneroptera falcata, and grasshoppers Euthystira brachyptera and Chorthippus parallelus. Several-year-old clear-cuts hosted a higher frequency of the grasshoppers Oedipoda caerulescens and Calliptamus italicus (Table 2).

The number of species differed significantly among the three age categories (one-way analysis ANOVA, $F=$ 28.45, $d f=2, P<0.001)$. The number of species increased between "age1" and "age2" (Tukey's multiple comparison: $P<0.001$; Fig. 2), but did not differ between "age2" and "age3" clear-cuts $(P=0.89$; Fig. 2$)$. The differences in abundance of the individual species in the three successional stages were also significant (ANOVA, $F=46.38, d f=2, P<0.001)$. The number of individuals in "age1" clear-cuts was significantly lower than in "age2", $(P<0.001$; Fig. 2) and lower still in "age2" than in "age3" $(P<0.001$; Fig. 2$)$. We recorded an increase in abundance, especially in the more numerous species of Ensifera (Pholidoptera griseoaptera, P. aptera, T. cantans), in D. verrucivorus and I. camptoxypha and in eight species of Caelifera (more numerous were Chorthippus vagans, $C$. brunneus, E. brachyptera). We found any decreasing abundance trend in Ensifera neither Caelifera species.

In the three age categories of clear-cuts there were significant differences in the abundance of 19 orthopteran species (Wilks' $\lambda=0.006, F_{38,24}=7.84, P<0.001$ ). The first discrimination function explains $73.1 \%$ of the variation in the data (Table 3), whereas both of the revealed discriminant functions were statistically significant $(P<$ 0.001). Tetrix tenuicornis, Calliptamus italicus, Chorthippus brunneus, C. parallelus, Chrysochraon dispar and $O$. caerulescens were not included in the model (Wilks' $\lambda=0.005-0.006$, Partial $\lambda=0.997-0.874$; Table 3; Fig. 3). This analysis resulted in a clear distinction between the three age categories of clear-cuts in terms of species composition and abundance of Orthoptera. In one-year-old clear-cuts, a typical species was T. undulata, in two-year-old clear-cuts Gomphocerripus rufus and 
TABLE 2. Percentages (\%) of the 27 species of Orthoptera, and total number of species and abundance (mean \pm SD) of Orthoptera occurring in 33 clear-cuts of three different age categories ("age1", "age2", "age3").

\begin{tabular}{|c|c|c|c|c|}
\hline Species & Abbr. & $\begin{array}{l}\text { "age1" } \\
(\mathrm{n}=11)\end{array}$ & $\begin{array}{l}\text { "age2" } \\
(\mathrm{n}=11)\end{array}$ & $\begin{array}{l}\text { "age3" } \\
(\mathrm{n}=11)\end{array}$ \\
\hline Barbitistes constrictus Br. v. Wattenwyl, 1878 & Bcon & & 27.3 & 27.3 \\
\hline Isophya camptoxypha (Fieber, 1853) & Icam & 9.1 & 18.2 & 36.4 \\
\hline Phaneroptera falcata (Poda, 1761) & Pfal & 36.4 & 90.9 & 81.8 \\
\hline Meconema thalassinum (Degeer, 1773) & Mtha & 9.1 & 27.3 & 18.2 \\
\hline Decticus verrucivorus (Linnaeus, 1958) & Dver & & 9.1 & 36.4 \\
\hline Metrioptera roeselii (Hagenbach, 1822) & Mroe & & 27.3 & 9.1 \\
\hline Pholidoptera aptera Mařan, 1953 & Papt & 9.1 & 27.3 & 63.6 \\
\hline Pholidoptera griseoaptera (Degeer, 1773) & Pgri & 100 & 100 & 100 \\
\hline Platycleis albopunctata grisea (Fabricius, 1781) & $P \lg r$ & & 45.5 & 18.2 \\
\hline Tettigonia cantans (Fussli, 1775) & Tcan & 45.5 & 100 & 100 \\
\hline Tettigonia viridissima Linnaeus, 1758 & Tvir & & 45.5 & \\
\hline Gryllus campestris Linnaeus, 1758 & Gcam & & 27.3 & 27.3 \\
\hline Tetrix bipunctata (Linnaeus, 1758) & Tbip & 36.4 & 45.5 & 27.3 \\
\hline Tetrix subulata (Linnaeus, 1758) & $T s u b$ & 18.2 & 72.7 & 36.4 \\
\hline Tetrix undulata (Sowerby, 1806) & Tund & 90.9 & 90.9 & 27.3 \\
\hline Tetrix tenuicornis Sahlberg, 1893 & Tten & 45.5 & 63.6 & 72.7 \\
\hline Calliptamus italicus (Linnaeus, 1758) & Cita & 9.1 & 27.3 & 63.6 \\
\hline Oedipoda caerulescens (Linnaeus, 1758) & Ocae & & 27.3 & 72.7 \\
\hline Euthystira brachyptera (Ocskay, 1826) & Ebra & 36.4 & 90.9 & 100 \\
\hline Gomphocerippus rufus (Linnaeus, 1758) & Gruf & & 27.3 & 18.2 \\
\hline Chorthippus biguttulus (Linnaeus, 1758) & Cbig & & 36.4 & 9.1 \\
\hline Chorthippus brunneus (Thunberg, 1815) & Cbru & 81.8 & 63.6 & 81.8 \\
\hline Chorthippus dorsatus (Zetterstedt, 1821) & Cdor & & 18.2 & \\
\hline Chorthippus montanus (Charpentier, 1825) & Cmon & & & 9.1 \\
\hline Chorthippus parallelus (Zetterstedt, 1821) & Cpar & 18.2 & 90.9 & 72.7 \\
\hline Chorthippus vagans (Eversmann, 1848) & Cvag & 90.9 & 90.9 & 100 \\
\hline Chrysochraon dispar (Germar, 1834) & Cdis & 9.1 & 36.4 & 72.7 \\
\hline Total species number & & $6.45 \pm 1.64$ & $13.27 \pm 3.00$ & $12.82 \pm 2.27$ \\
\hline Total abundance & & $64.18 \pm 22.35$ & $144.36 \pm 46.45$ & $255.64 \pm 70.43$ \\
\hline
\end{tabular}

Gryllus campestris and in several-year-old clear-cuts fringe species such as Phaneroptera falcata, Pholidoptera aptera and the grassland species D. verrucivorus and E. brachyptera (Table 3 ).

There was a significant correlation between the number of species of Orthoptera and the following two abiotic characteristics of the clear-cuts: (a) elevation (Pearson's correlation; $t=2.92, d f=31, P=0.006, r=0.46$ ); (b) total area of all the clear-cuts regardless of their age (Spearman's rank correlation rho; $S=2142.14, P<0.001$, $r=0.64)$. The number of species was also correlated with the area of two-year-old clear-cuts (Pearson's correlation; $t=2.98, d f=9, P=0.016, r=0.70)$, but not with the area of one-year-old (Pearson's correlation; $P>0.05$ ) and several-year-old clear-cuts (Pearson's correlation; $P>$ $0.05)$.

\section{Specific associations between species of Ensifera and Caelifera and the structure of the vegetation and age of the clear-cuts}

We found differences in the colonization of all clearcuts by the two taxonomic groups, bush-crickets (Ensifera) and grasshoppers (Caelifera), studied. CCA models display the variability in the species spectrum and abundance of both Ensifera and Caelifera along two ordination axes (eigenvalues: CCA1 $=0.045, \mathrm{CCA} 2=0.024$ for Ensifera; Fig. 4A and CCA1 $=0.239, \mathrm{CCA} 2=0.048$ for Caelifera; Fig. 4B). The bush-crickets (Ensifera) colonized the deforested areas last. Apart from the species $P$. griseoaptera, characteristic of fragmented forest landscapes, there were fewer species of Ensifera in "age1" than older clear-cuts (Table 2). In the "age2" clear-cuts there were the strong flying Ensifera, such as Tettigonia viridissima, Phaneroptera falcata and Platycleis grisea, and, surprisingly, also the brachypterous grassland species G. campestris and Metrioptera roeselii. In the older clear-cuts ("age3") another grassland species, D. verrucivorus, also occurred (Fig. 4A).

The grasshoppers (Caelifera) colonized deforested plots in the first year and several of them were associated with successional stages present at the end of the second year and are mostly species occurring on bare-soil and in ground vegetation, such as species of the genera Tetrix and Chorthippus (C. brunneus, C. vagans, C. biguttulus) and the species $G$. rufus. Older successional stages (3-7 years) provided an environment favourable for grassland species (E. brachyptera, Chrysochraon dispar, Chorthippus parallelus) and for species of bare ground habitats (C. italicus and O. caerulescens; Fig. 4B).

Response of Ensifera to the structure of the vegetation is described in terms of the eigenvalues of the CCA 

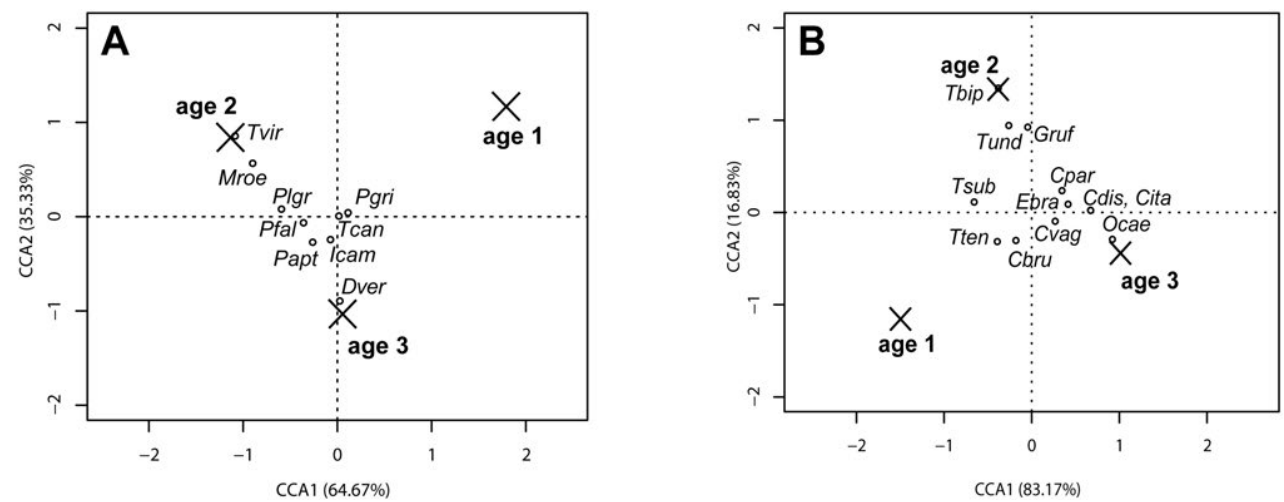

Fig. 4. Classification of species of Ensifera (A) and Caelifera (B) in relation to three clear-cut age categories. The abbreviations for each species are listed in Table 2; "age1"-“age 3", see Methods.

model: $\mathrm{CCA} 1=0.065, \mathrm{CCA} 2=0.018$ (Fig. $5 \mathrm{~A}$ ), which was more pronounced for Caelifera (eigenvalues: CCA1 $=0.236$, CCA $2=0.104 ;$ Fig. $5 \mathrm{~B})$, regardless the ages of the clear-cut. We found that the presence of species of Ensifera were not associated with bare soil or the presence of Rubus spp. In contrast, their presence was associated with the height of the vegetation and presence of herbaceous plants and grasses. The presence of shrubs was clearly important for the occurrence of the bushcricket $T$. viridissima (Fig. 5A). We recorded several grasshopper species occurring in deforested plots where there were large areas of bare soil and large quantities of dead wood (Chorthippus vagans, C. brunneus, G. rufus, Tetrix bipunctata, T. tenuicornis), or a few herbaceous plants (Fig. 5B). The graminicolous species were mostly associated with grassland (Chorthippus parallelus, $O$. cearulescens, Calliptamus italicus), with Chrysochraon dispar and E. brachyptera, exhibiting a positive correlation with the height of the vegetation (Fig. 5B).

\section{DISCUSSION}

\section{Colonization of clear-cuts by Orthoptera}

Our study of the colonization of clear-cuts in beech forest by Orthoptera support our assumption that heliophilous Orthoptera are quick to colonize newly created open areas. As early as in the second year, the newly created clear-cuts hosted 27 of the species that were recorded in all the age categories of clear-cuts (1-7 years). We also thought that clear-cuts would be first colonized by species that naturally occur in forest clearings (Kati et al., 2003; Theuerkauf \& Rouys, 2006) and are good flyers, e.g. Chorthippus vagans (Hochkirch et al., 2008), Chorthippus brunneus (Laußmann, 1993; Jenni et al., 2007) and macropterous individuals of primarily brachypterous

TABLE 3. Relative importance of 19 species based on the DFA (the lower the value of Wilks' $\lambda$, the more important the species) and standardized coefficients of the canonical roots.

\begin{tabular}{|c|c|c|c|c|c|}
\hline Species & Wilks' $\lambda$ & $\begin{array}{c}F \text {-remove } \\
(2,8)\end{array}$ & $p$-level & Root 1 & Root 2 \\
\hline Euthystira brachyptera (Ocskay, 1826) & 0.011 & 5.57 & 0.019 & 1.53 & 0.47 \\
\hline Tettigonia viridissima Linnaeus, 1758 & 0.013 & 7.88 & 0.007 & -2.03 & 0.41 \\
\hline Chorthippus vagans (Eversmann, 1848) & 0.006 & 0.92 & 0.425 & -0.72 & 0.54 \\
\hline Gomphocerippus rufus (Linnaeus, 1758) & 0.029 & 25.12 & 0.001 & -3.68 & 0.54 \\
\hline Barbitistes constrictus Br. v. Wattenwyl, 1878 & 0.021 & 16.94 & 0.001 & -1.89 & 0.11 \\
\hline Meconema thalassinum (Degeer, 1773) & 0.009 & 3.48 & 0.064 & 2.43 & -0.48 \\
\hline Tetrix subulata (Linnaeus, 1758) & 0.017 & 12.49 & 0.001 & -2.16 & 0.73 \\
\hline Chorthippus biguttulus (Linnaeus, 1758) & 0.006 & 0.95 & 0.415 & -0.72 & -0.06 \\
\hline Phaneroptera falcata (Poda, 1761) & 0.008 & 2.39 & 0.134 & 0.7 & 0.94 \\
\hline Tetrix undulata (Sowerby, 1806) & 0.009 & 3.21 & 0.076 & 1.57 & -0.61 \\
\hline Decticus verrucivorus (Linnaeus, 1958) & 0.012 & 6.64 & 0.011 & 1.43 & 0.63 \\
\hline Pholidoptera aptera Mařan, 1953 & 0.007 & 2.06 & 0.17 & 1.31 & 0.88 \\
\hline Gryllus campestris Linnaeus, 1758 & 0.013 & 8.08 & 0.006 & -3.78 & 0.45 \\
\hline Pholidoptera griseoaptera (Degeer, 1773) & 0.007 & 2.05 & 0.172 & -0.94 & 0.08 \\
\hline Tettigonia cantans (Fussli, 1775) & 0.007 & 1.78 & 0.21 & -0.61 & 0.43 \\
\hline Metrioptera roeselii (Hagenbach, 1822) & 0.012 & 7.01 & 0.01 & 2.91 & -0.56 \\
\hline Platycleis albopunctata grisea (Fabricius, 1781) & 0.01 & 4.66 & 0.032 & -2.23 & -0.15 \\
\hline Tetrix bipunctata (Linnaeus, 1758) & 0.009 & 3.9 & 0.05 & -1.23 & 0.03 \\
\hline Isophya camptoxypha (Fieber, 1853) & 0.007 & 1.27 & 0.315 & 0.71 & -0.22 \\
\hline Eigenvalues & & & & 20.25 & 7.47 \\
\hline Cummulative proportion & & & & 0.73 & 1.00 \\
\hline
\end{tabular}



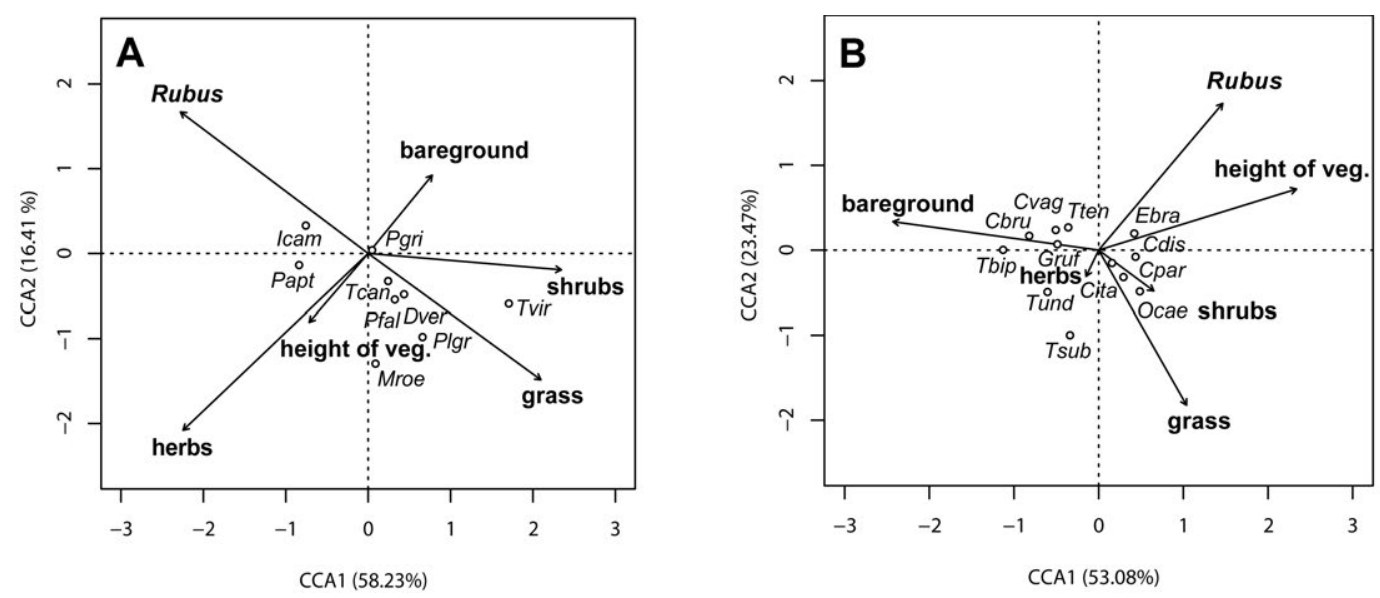

Fig. 5. Classification of species of Ensifera (A) and Caelifera (B) in relation to six structural categories of vegetation (bare ground, grass, herbs, shrubs, Rubus spp. and height of vegetation). The species abbreviations are listed in Table 2.

species (Poniatowski \& Fartmann, 2011b). We found that of the total number of species recorded two thirds were capable of flying. However, the brachypterous bushcricket $P$. griseoaptera was recorded most frequenly and was the most abundant species in all deforested plots where dead wood, shrubs and ecotones abounded (cf. Diekötter et al., 2005, 2009). Of the Caelifera group, the most frequent species in all age categories of clear-cuts was the long-winged species $C$. vagans, which is an inhabitant of forest edges and sparse forests (Hochkirch et al., 2008). Colonization by some long-winged species of Caelifera, e.g. Calliptamus italicus and Oedipoda caerulescens, might be impeded by the nature of the landscape relief, which is well known to affect the distribution of brachypterous ground dwelling species (Kaňuch et al., 2012). Closed canopy forests are another barrier for flying heliophilous species of Orthoptera (Gerber \& Templenton, 1996). Primary brachypterous species, e.g. E. brachyptera, C. parallelus and M. roeselii, colonize clearcuts later on when the microclimate there is more suitable in terms of a high light intensity and the composition and structure of the vegetation. These conditions occur more consistently after the first year following tree-cutting (Clayton, 2002; Kati et al., 2003; Jenni et al., 2007). The significant increase in the number and abundance of species in "age2" clear-cuts may be due to the greater heterogeneity in vegetation and food supply in them compared to "age1" clear-cuts (Guido \& Gianelle, 2001). We also suppose that in "age1" clear-cuts with a high proportion of bare ground and low habitat heterogeneity, the roosting and foraging conditions for some species of Orthoptera are unsuitable. Furthermore, species might be exposed to a higher risk of predation in open habitats (Berggren et al., 2001). We found no marked differences in vegetation characteristics of "age2" and "age3" clearcuts (c.f. Godefroid et al., 2005), which is reflected in the small differences in the numbers of species of Orthoptera recorded in them. Higher numbers of species in "age3" than "age2" clear-cuts can be attributed to the greater colonization of older clear-cuts and more species reproducing in them.

\section{Environmental factors associated with the occurrence of Orthoptera in clear-cuts}

Environmental factors can significantly influence the distribution and species richness in various habitats and countries (Theuerkauf \& Rouys, 2006; Báldi, 2008; Marini et al., 2008; Fabriciusová et al., 2011; Essl \& Dirnböck, 2012). We found that small-area clear-cuts may play an important role in determining the insect biodiversity in homogenous closed canopy forests. Clearcuts in closed forest are not only new open habitats but also new forest edges, which enhance the diversity of insects and other animals (e.g. Horváth et al., 2000; Bouget \& Duelli, 2004; Deans et al., 2005). Clear-cutting and thinning small areas of forest can do today what was done in the past by large herbivores in terms of clearing areas of vegetation and creating new forest edges (Bengtsson et al., 2000; Konvička et al., 2004). Our study of Orthoptera revealed that there are more species in clear-cuts and at the forest edges than in the interior of the surrounding forest, forest clearings and grassland (Sliacka \& Krištín, 2012). We recorded a total of 27 species in all three age categories of clear-cuts, which is more than reported by other authors in deforested plots (Detzel 1998; Clayton, 2002; Jenni et al., 2007). This may be due to differences in orthopteran species richness of different countries (compare Detzel, 1998 for Baden Württemberg, Germany; Thorens \& Nadig, 1997 for Switzerland, Kočárek et al., 2005 for Czech and Slovak Rebublics).

The overall area of habitat suitable for Orthoptera is considered to be an essential factor determining their presence and composition (e.g. Bergmann \& Chaplin, 1992; Theuerkauf \& Rouys, 2006). In our study, we confirmed that the number of species increased with increase in the area of all the age categories of the clear-cuts studied. Clear-cuts on steeper slopes were drier and the succession there was slower than in those in less steep areas, which resulted in the higher number of xerothermophilous species (e.g. C. italicus, O. caerulescens, G. rufus) recorded in this study. 

Specific associations between species of Ensifera and
Caelifera with the vegetation and age of the clear-cuts

It is well known that Ensifera are mainly associated with shrubs and Caelifera with bare soil and grassland (Ingrisch \& Köhler, 1998). Because changes in the structure of vegetation are not always age dependent, we evaluated the association between changes in Ensifera and Caelifera assemblages and the age and characteristics of the vegetation, separately .

In "age1" plots, species of Caelifera were dominant and consisted most frequently of the ground dwelling generalist species of the genus Tetrix, and Chorthippus brunneus and C. vagans (cf. Detzel, 1998), which supports the findings of Jenni et al. (2007) recorded in burnt areas in Swiss coniferous forests. For "age2" plots we confirm that other species of Caelifera occur, namely the graminicolous $C$. parallelus and E. brachyptera, as previously recorded (Laußmann, 1993). However, two year old clear-cuts were also well colonized by many species of Ensifera, the most frequent being the good fliers Tettigonia viridissima, T. cantans, Phaneroptera falcata and Platycleis grisea.

We found differences in the association between species of Ensifera and Caelifera and six categories of vegetation. This is a result of the differences in their habitat requirements (Guido \& Gianelle, 2001) and food (Shields et al., 2008), which are linked to the structure of the vegetation in different successional stages of the clear-cuts (Schmidt \& Schlagbauer, 1965; Marini et al., 2009a; Fabriciusová et al., 2011; Fartmann et al., 2012). Bare ground in new clear-cuts provides favourable conditions for terricolous, xerophilous and thermophilous grasshopper species of the genus Tetrix, and Chorthippus brunneus, $C$. biguttulus, C. vagans, O. caerulescens and Calliptamus italicus (cf. Jenni et al., 2007). The low and sparse vegetation in "age1" clear-cuts was probably not suitable for the species of Ensifera that are good flyers (e.g. $P$. falcata, Tettigonia cantans, T. viridissima) and therefore likely to be early colonizers. We confirmed that colonization by graminicolous grassland species, especially grasshoppers such as Chorthippus parallelus, E. brachyptera and Chrysochraon dispar (cf. Guido \& Gianelle, 2001), and the bush-crickets $P$. falcata and $M$. roeselii is associated with presence of grassy patches in clear-cuts. The number of species of Ensifera is positively associated with the presence of shrubs (Kati et al., 2003; Marini et al., 2009a; Fabriciusová et al., 2011; Fartmann et al., 2012). In clumps of shrubs and Rubus spp., we recorded the bush-crickets Tettigonia cantans, T. viridissima and a common species, $P$. griseoaptera, as well as occasionally Meconema thalassinum, Barbitistes constrictus and Isophya camptoxypha. However, this may be an underestimate due to the sampling methods used, according to Dalbeck (2011). In addition, the association of the bushcricket, $T$. viridissima, with shrubs is also recorded by Schirmel et al. (2011). We also confirmed that the number of graminicolous species of Caelifera is negatively associated with a high proportion of tall trees and shrubs in clear-cuts as is recorded in studies of grassland (cf. Bieringer \& Zulka, 2003; Marini et al., 2009a).

The main contribution of this study is recognition that certain key factors (clear-cut age and vegetation structure) affect the colonization of clear-cuts in beech forests by Orthoptera. The diverse structure of the vegetation and the size of the clear-cuts may account for why they were quickly colonized by all of the 27 species of Orthoptera recorded by the end of the second year after felling the trees. The higher proportion of Ensifera recorded in this compared to previous studies also indicates that there was a high proportion of shrub and tree vegetation in the plots we studied.

When and under what conditions such clear-cuts no longer enhance the diversity of heliophilous species in closed canopy forests is a question that remains to be answered.

ACKNOWLEDGEMENTS. We acknowledge our colleague P. Kaňuch, anonymous referees and the editor for their comments and advice and P. Tuček, M. Mikuš, J. Bystriansky for their help with the field work. This study was funded by grants from the Slovak Grant Agency (VEGA 2/0157/11, APVV 0497-10).

\section{REFERENCES}

BÁLDI A. 2008: Habitat heterogeneity overrides the species-area relationship. - J. Biogeogr. 35: 675-681.

Bengtsson J., Nilsson S.G., Franc A. \& Menozzi P. 2000: Biodiversity, disturbances, ecosystem function and management of Europaean forests. - Forest Ecol. Manag. 132: 39-50.

BergGren Å., Birath B. \& Kindvall O. 2002: Effect of corridors and habitat edges on dispersal behavior, movement rates, and movement angles in Roesel's bush-cricket (Metrioptera roeseli). - Conserv. Biol. 16: 1562-1569.

Berggren Å., Carlson A. \& Kindvall O. 2001: The effect of landscape composition on colonisation success, growth rate and dispersal in introduced bush-crickets Metrioptera roeselii. - J. Anim. Ecol. 70: 663-670.

Bergmann D.J. \& Chaplin S.J. 1992: Correlates of species composition of grasshopper (Orthoptera: Acrididae) communities on Ozark cedar glades. - Southw. Nat. 37: 362-371.

Bieringer G. \& ZULKa K.P. 2003: Shading out species richness: edge effect of a pine plantation on the Orthoptera (Tettigoniidae and Acrididae) assemblage of an adjacent dry grassland. - Biodiv. Conserv. 12: 1481-1495.

Bouget C. \& Duelli P. 2004: The effects of windthrow on forest insect communities: a literature review. - Biol. Conserv. 118: 281-299.

BRANSON D.H. 2011: Relationships between plant diversity and grasshopper diversity and abundance in the Little Missouri National grassland. - Psyche. ID748635, 7 pp.

Buchwertz M. 1993: Zur Ökologie der Rotflügeligen Schnarrschrecke (Psophus stridulus L. 1758) unter besonderer Berücksichtigung der Mobilität, Populationsstruktur und Habitatwahl. - Articulata 8: 39-62.

Clayton J.C. 2002: The effects of clearcutting and wildfire on grasshoppers and crickets (Orthoptera) in an intermountain forest ecosystem. - J. Orthopt. Res. 11: 163-167.

DALBECK L. 2011: Biberlichtungen als Lebensraum für Heuschrecken in Wäldern der Eifel. - Articulata 26: 97-108.

Deans A.M., Malcolm J.R., Smith S.M. \& Belloce M.I. 2005: Edge effects and the responses of aerial insect assemblages to structural-retention harvesting in Canadian boreal peatland forests. - Forest Ecol. Manag. 204: 249-266.

Detzel P. 1998: Die Heuschrecken Baden-Württembergs. Stutgart, Ulmer, $580 \mathrm{pp}$. 
Diekötter T., Csencsics D., Rothenbühler C., Billeter R. \& EDWARDS P.J. 2005: Movement and dispersal patterns in the bush cricket Pholidoptera griseoaptera: the role of developmental stage and sex. - Ecol. Entomol. 30: 419-427.

Diekötter T., Baveco H., Arens P., Rothenbühler C., Billeter R., Csencsics D., De Filippi R., Hendrickx F., Speelmans M., Opdam P. \& Smulders M.J.M. 2009: Patterns of habitat occupancy, genetic variation and predicted movement of a flightless bush cricket, Pholidoptera griseoaptera, in an agricultural mosaic landscape. - Landsc. Ecol. 25: 449-461.

EssL F. \& DirnBöcK T. 2012: What determines Orthoptera species distribution and richness in temperate semi-natural dry grassland remnants? - Biodiv. Conserv. 21: 2525-2537.

FABRiciusová V., Kañuch P. \& KRIŠTín A. 2011: Response of Orthoptera assemblages to management of montane grasslands in the Western Carpathians. - Biologia 66: 1127-1133.

Fartmann T., Krämer B., Stelzner F. \& Poniatowski D. 2012 Orthoptera as ecological indicators for succession in steppe grassland. - Ecol. Indicat. 20: 337-344.

Gardiner T., Hill J. \& Chesmore D. 2005: Review of the methods frequently used to estimate the abundance of Orthoptera in grassland ecosystems. - J. Insect Conserv. 9: $151-173$.

Gerber A.S. \& Templeton A.R. 1996: Population sizes and within-deme movement of Trimerotropis saxatilis (Acrididae), a grasshopper with a fragmented distribution. - Oecologia 105: 343-350.

Godefroid S., Rucquoij S. \& Koedam N. 2005: To what extent do forest herbs recover after clearcutting in beech forest. Forest Ecol. Manag. 210: 39-53.

Guido M. \& Gianelle D. 2001: Distribution patterns of four Orthoptera species in relation to microhabitat heterogeneity in an ecotonal area. - Acta Oecol. 22: 175-185.

HARRISON R.G. 1980: Dispersal polymorphisms in insects. Annu. Rev. Ecol. Syst. 11: 95-118.

Hochkirch A., GärTnER A.C. \& BrandT T. 2008: Effects of forest-dune ecotone management on the endangered heath grasshopper, Chorthippus vagans (Orthoptera: Acrididae). Bull. Entomol. Res. 98: 449-456.

Horváth R., Magura T., Péter G. \& Bayar K. 2000: Edge effect on weevil and spider communities at the Bükk National Park in Hungary. - Acta Zool. Acad. Sci. Hungar. 46: $275-290$.

Ingrisch S. \& KöHLer G. 1998: Die Heuschrecken Mitteleuropas. Westarp Wissenschaften, Magdeburg, 460 pp.

Jenni S., Walter T., Moretti M., Jeanneret P., Obrist M.K. \& Duelli P. 2007: Auswirkungen von Feuer, Meereshöhe und Vegetation auf die Heuschreckenfauna im Waldbrandgebiet oberhalb Leuk im Wallis. — Mitt. Schweiz. Entomol. Ges. 80: 253-269.

JordÁn F., BÁldi A., Orci K.-M., RÁcz I. \& VARGA Z. 2003: Characterizing the importance of habitat patches and corridors in maintaining the landscape connectivity of a Pholidoptera transsylvanica (Orthoptera) metapopulation. - Landsc. Ecol. 18: 83-92.

Kaňuch P., JarčušKa B., Schlosserová D., Sliacka A., Paule L. \& KRIŠTín A. 2012: Landscape configuration determines gene flow and phenotype in a flightless forest-edge grounddwelling bush-cricket, Pholidoptera griseoaptera. - Evol. Ecol. 26: 1331-1343.

Kati V., Dufrêne M., Legakis A., Grill A. \& Lebrun P. 2003: Conservation management for Orthoptera in the Dadia reserve, Greece. - Biol. Conserv. 115: 33-44.

KočÁReK P., HolušA J. \& VidLIČKA L. 2005: Blattaria, Mantodea, Orthoptera \& Dermaptera of the Czech and Slovak Republics. Kabourek, Zlín, 349 pp.

Kohlmann B. \& SHAw D. 1991: The effect of a partial barrier on the movement of a hybrid zone. - Evolution 45: 1606-1617.

KONVIČKA M., ČÍžEK L. \& BENEŠ J. 2004: Ohrožený hmyz nízinných lesư: Ochrana a management. [Endangered Insects of Lowland Forests: Conservation and Management.] Sagittaria, Olomouc, 79 pp. [in Czech].

LAUSSMANN H. 1993: Die Besiedlung neu entstandener Windwurflächen durch Heuschrecken. - Articulata 8: 53-59.

Marini L., Fontana P., Scotton M. \& KlimeK S. 2008: Vascular plant and Orthoptera diversity in relation to grassland management and landscape composition in the European Alps. J. Appl. Ecol. 45: 361-370.

Marini L., Fontana P., Battisti A. \& Gaston K.J. 2009a: Response of orthopteran diversity to abandonment of seminatural meadows. - Agric. Ecosyst. Environ. 132: 232-236.

Marini L., Fontana P., Battisti A. \& Gaston K.J. 2009b: Agricultural management, vegetation traits and landscape drive orthopteran and butterfly diversity in a grassland-forest mosaic: a multi-scale approach. - Insect Conserv. Diver. 2: 213-220.

Niemelä J., Koivula M. \& Kotze D.J. 2007: The effects of forestry on carabid beetles (Coleoptera: Carabidae) in boreal forests. - J. Insect Conserv. 11: 5-18.

Oksanen J.F., Blanchet G., Kindt R., Logendre P., Minchin P.R., O’Hara R.B., Simpson G.L., Solymos M., Stevens H.H., \& Wagner H. 2012. Vegan: Community Ecology Package. $R$ Package Version 2.0-5. http://CRAN.R-project.org/package= vegan

Picaud F. \& Petit D.P. 2007: Primary succession of Acrididae (Orthoptera): Differences in displacement capacities in early and late colonisers of new habitats. - Acta Oecol. 32: 59-66.

Poniatowski D. \& FARTMAnN T. 2011a: Weather-driven changes in population density determine wing dimorphism in a bushcricket species. - Agric. Ecosyst. Environ. 145: 5-9.

Poniatowski D. \& Fartmann T. 2011b: Does wing dimorphism affect mobility in Metrioptera roeselii (Orthoptera: Tettigoniidae)? — Eur. J. Entomol. 108: 409-415.

Poore M.E.D. 1955: The use of phytosociological methods in ecological investigations: I. The Braun-Blanquet System. J. Ecol. 43: 226-244.

SchelhaAs M.J., NabuUrs G.J. \& Schuck A. 2003: Natural disturbances in the European forests in the 19th and 20th centuries. - Glob. Change Biol. 9: 1620-1633.

Schirmel J., Mantilla-Contreras J., Blindow I. \& Fartmann T 2011: Impact of succession and grass encroachment on heathland Orthoptera. — J. Insect Conserv. 15: 633-642.

Schmidt G.H. \& Schlagbauer A. 1965: Die Orthopteren-Fauna und Pflanzengesellschaften der Kahlschläge des Arbergebietes im Bayerischen Wald, mit einem Beitrag zum Problem der Makropterie. - Z. Morph. Ökol. Tiere 54: 643-668.

Shields J.M., Webster C.R. \& Storer A.J. 2008: Short-term community-level response of arthropods to group selection with seed-tree retention in a northern hardwood forest. Forest Ecol. Manag. 255: 129-139.

SLIACKA A. \& KrišTín A. 2012: Orthopteran assemblages in early succession stages of clear-cuts and grasslands in fragmented beech forests. - Folia Faun. Slov. 17: 361-367.

Theuerkauf J. \& Rouys S. 2006: Do Orthoptera need human land use in Central Europe? The role of habitat patch size and linear corridors in the Bialowieza Forest, Poland. - Biodivers. Conserv. 15: 1497-1508.

Thorens P. \& Nadig A. 1997: Atlas de Distribution des Orthoptères de Suisse: Sauterelles, Grillons, Criquets (Orthoptera), et Mante Religieuse (Mantodea). Centre Suisse de Cartographie de la Faune, Pro Natura, Neuchâtel, 236 pp.

Vele A., Holuša J., Frouz J. \& KonvičKa O. 2011: Local and landscape drivers of ant and carabid beetle communities during spruce forest succession. - Eur. J. Soil Biol. 47: 349-356.

Willott S.J., Lim D.C., Compton S.G. \& Sutton S.L. 2000: Effects of selective logging on the butterflies of a Bornean rainforest. - Conserv. Biol. 14: 1055-1065.

Received June 27, 2012; revised and accepted November 16, 2012 